\title{
ANALISIS PENGAKUAN DAN PENGUKURAN PENDAPATAN \\ BERDASARKAN PSAK NO. 23 PADA PT. BAKTI GRAHASTA \\ MANDIRI
}

Oleh :

\author{
Galih Chandra Kirana, SE.,M.Ak \\ Dan \\ Andi Chandra
}

Fakultas Ekonomi Jurusan Akuntansi

Universitas Satya Negara Indonesia

\begin{abstract}
ABSTRAK
Pengakuan perlu dilakukan pada saat yang tepat atas suatu kejadian ekonomi yang menghasilkan pendapatan, begitu juga jumlah yang diakui haruslah diukur secara tepat dan pasti agar tidak mengakibatkan kesalahan informasi yang disajikan dalam laporan laba rugi juga dalam pengambilan keputusan. Penelitian ini bertujuan untuk mengetahui apakah pengakuan dan pengukuran pendapatan pada PT. Bakti Garhasta Mandiri telah sesuai dengan PSAK No. 23. Metode penelitian yang digunakan adalah studi deskriptif dengan menggunakan data sekunder. Hasil penelitian menunjukkan bahwa pengakuan dan pengukuran pendapatan pada PT. Bakti Grahasta Mandiri telah sesuai dengan Pernyataan Standar Akuntansi Keuangan No.23. Dimana pengakuan pendapatan perusahaan menggunakan metode accrual basis yakni pendapatan diakui pada saat terjadinya transaksi penjualan jasa oleh perusahaan. Pengakuan pendapatan perusahaan telah mengacu pada PSAK No. 23 terlihat dari nilai penjualan jasa yang dicatat sebagai pendapatan tersebut dapat diestimasi dengan pasti dan besar kemungkinannya dapat direalisasikan. Pengukuran pendapatan menggunakan dasar pengukuran historis berdasarkan nilai wajar imbalan yang diterima atau yang akan diterima dalam bentuk kas dan setara kas.
\end{abstract}

Kata kunci: pengakuan, pengukuran, pendapatan, PSAK No.23 


\begin{abstract}
Recognition needs to be done at the right moment on the economic events generated revenue, as well as the amount recognized should be measured precisely and surely that doesn't result in misinformation presented and decision making. This research aimed to find out whether the revenue recognition and measurement at PT.Bakti Grahsta Mandiri was adjusted with PSAK No.23. The research method uses descriptive study with primary and secondary data. The research result is show that the revenue recognition and measurement at PT. Bakti Grahasta Mandiri was adjusted under Financial Statement Accounting Standard No.23.where the company recognition revenue used accrual basis method, that the revenue recognized when the service sales transactions happened. Recognition of the company's revenue has been referred to in PSAK No. 23 seen from the value of service sales are recorded as revenue can be estimated with certainty and likely to be realized. Revenue measurement used historical measurement basic based on fair value exchange that received or will be received in cash or cash equivalent.
\end{abstract}

Keywords: recognition, measurement, revenue, statement financial accounting standard No.23 


\section{Latar Belakang}

\section{PENDAHULUAN}

Pada perusahaan jasa kegiatan utamanya memberikan pelayanan melalui jasa yang diberikan. Di dalam dunia jasa penginapan setiap perusahan ingin mencari pendapatan yang sangat besar, berbagai macam cara yang dilakukan untuk memajukan perusahaan. Meskipun terjadi persaingan antara perusahaan untuk mempertahankan kelangsungan hidup perusahaan, namun hal inilah yang pada dasarnya memacu setiap perusahaan untuk memberikan pelayanan lebih baik lagi demi mencari pendapatan.

Pendapatan merupakan unsur penting dalam menyajikan informasi pada laporan laba rugi. Jika pendapatan lebih besar dari pada biaya yang telah dibebankan maka perusahaan memperoleh laba, namun sebaliknya jika pendapatan lebih kecil dari pada biaya yang telah dibebankan maka perusahaan mengalami kerugian. Salah satu penentu besarnya laba atau rugi adalah pendapatan, pengakuan pendapatan menjadi permasalahan dalam menentukan pendapatan.

Pengakuan pendapatan merupakan saat dimana sebuah transaksi harus diakui sebagai pendapatan perusahaan. Sedangkan pengukuran pendapatan adalah berapa besar jumlah pendapatan yang seharusnya diakui dari setiap transaksi yang terjadi pada suatu periode tertentu. Permasalahan pengakuan dan pengukuran pendapatan saling terkait satu sama lain. Permasalahan ini akan selalu muncul apabila sebuah transaksi berhubungan dengan pendapatan. Pengakuan perlu dilakukan pada saat yang tepat atas suatu kejadian ekonomi yang menghasilkan pendapatan, begitu juga jumlah yang diakui haruslah diukur secara tepat dan pasti. Perusahaan menggunakan metode accrual basis dalam pendapatnya Penjualan jasa terdiri dari penjualan tunai dan penjualan jasa secara tunai bagi tamu dapat diakui pendapatanya secara tepat. Pada setiap periode akuntansi perusahaan pada umumnya akan membuat laporan keuangan.

Dalam akuntansi pendapatan permasalahan utama adalah pada saat pengakuan itu diakui. Permasalahan ini akan terus muncul bila terjadi transaksi yang berhubungan dengan pendapatan. Jumlah pendapatan yang dihasilkan perusahaan harus diukur dengan pasti. Analisa yang baik akan membantu perusahaan dalam kelangsungan hidup perusahaan dimasa yang akan datang. Jika perusahaan keliru dalam menentukan pendapatan maka akan mengakibatkan salah dalam pengambilan keputusan.Untuk mengatasi permasalahan diatas, maka disusunlah Standar Akuntansi Keuangan oleh Ikatan Akuntan Indonesia. Standar ini berlaku di Indonesia dan merupakan pedoman resmi yang digunakan perusahaan dalam penyajian laporan keuangan. Dalam standar keuangan akuntansi juga memuat tentang pengakuan dan pengukuran pendapatan. Dengan adanya standar ini, maka laporan laba rugi perusahaan bisa dipercaya kebenarannya.

Di dalam PSAK No. 23 diuraikan dan dijelaskan tentang pengakuan dan pengukuran pendapatan yang dapat digunakan bagi perusahaan - perusahaan. PT. Bakti Grahasta Mandiri adalah merupakan salah satu perusahaan jasa penginapan yang terletak di Jakarta Selatan. Sebagai perusahaan berorientasi bisnis yang bergerak dalam bidang jasa penginapan untuk umum yang menggunakan jasa tersebut. 
Aktivitas utama PT. Bakti Grahasta Mandiri dalam memperoleh pendapatan yaitu hasil penjualan kamar, hasil penjualan ruang rapat, makan dan minum, laundry dan dimana penerimaan pendapatannya ini dapat dilakukan secara tunai. Penjualan jasa secara tunai bagi tamu umum dapat diakui pendapatannya secara tepat. PT. Bakti Grahasta Mandiri ini merupakan perusahaan yang belum go publik, sehingga memungkinkan untuk dianalisis pada penerapan perlakuan akuntansi mengenai pengakuan dan pengukuran pendapatannya dimana harus disesuaikan dengan PSAK Nomor 23 mengenai pendapatan agar dalam pelaporan keuangan perusahaan dapat mencerminkan informasi keuangan yang akurat bagi pemakai laporan keuangan.

Pengakuan dan pengukuran pendapatan perusahaan memerlukan analisa terhadap tingkat penyelesaian suatu transaksi dan harus mempertimbangkan estimasi hasil transaksi apakah dapat diestimasi dengan andal atau tidak. Hal ini tentunya membutuhkan berbagai macam pertimbangan perusahaan agar dapat mengakui dan mengukur pendapatan dengan andal atas jasa yang diberikan serta dapat mencerminkan jumlah pendapatan yang dihasilkan pada periode tersebut. Mengingat pentingnya arti pendapatan bagi perusahaan dan masalah-masalah yang mungkin timbul dalam pengakuan dan pengukuran pendapatan pada perusahaan jasa, mendorong peneliti untuk membahas masalah mengenai "Analisis Pengakuan dan Pengukuran Pendapatan Berdasarkan PSAK No.23 pada PT. Bakti Grahasta Mandiri.”

\section{Tujuan Penelitian}

Penelitian ini bertujuan untuk mengetahui pengakuan dan pengukuran pendapatan yang diterapkan dan sesuaikah dengan Pernyataan Standar Akuntansi keuanagan No.23.

\section{LANDASAN TEORI}

\section{Penelitian Terdahulu}

Penelitian oleh Budi Mulia (2007) dengan judul "Pengakuan dan Pengukuran Pendapatan Menurut PSAK No. 23 pada PT. Raya Utama Travel Medan" bertujuan untuk mengetahui sejauh mana metode pengakuan dan pengukuran pendapatan PT. Raya Utama Travel Medan dan menganalisa bagaimana proses pengakuan dan pengukurannya apakah telah sesuai dengan PSAK No.23. Hasil penelitian ini menunjukkan bahwa pengakuan dan pengukuran pendapatan telah sesuai dengan PSAK No. 23.

Worung (2012) melakukan penelitian dengan judul "Analisis Penerapan PSAK 23 terhadap Pengakuan dan Pengukuran Pendapatan pada PT. Telekomunikasi Indonesia Kandatel Manado". Penelitian ini bertujuan untuk mengetahui apakah pengakuan dan pengukuran pendapatan jasa telekomunikasi dengan adanya interkoneksi negara yang dihasilkan bersama oleh beberapa penyelenggara telah sesuai dengan Standar Akuntansi Keuangan yang berlaku. Hasil analisis menunjukkan bahwa pendapatan jasa telekomunikasi yang timbul dari interkoneksi diakui sebesar bagian pendapatan masingmasing penyelenggara yang ditentukan sesuai dengan perjanjian. 
Persamaan penelitian ini dengan penelitian sebelumnya terletak pada analisis penerapan perlakuan akuntansi pendapatan menurut PSAK No. 23 mengenai pendapatan. Sedangkan perbedaan terletak pada objek penelitian dimana difokuskan pada perusahaan jasa penginapan pada PT. Bakti Grahasta Mandiri.

\section{Pendapatan}

Pendapatan merupakan unsur yang sangat penting dalam laporan keungan, karena dalam melakukan suatu aktivitas usaha, manajemen perusahaan tentu ingin mengetahui nilai atau jumlah pendapatan yang diperoleh dalam suatu periode akutansi yang diakui sesuai dengan prinsip-prinsip yang berlaku umum.

Menurut Keiso, Warfield dan Wegant (2007: 516) pendapatan adalah arus kas masuk aktiva dan atau penyelesaian kewajiban akibat penyerahan atau produksi barang, pemberian jasa atau kegiatan menghasilkan laba lainnya yang membentuk operasi utama atau inti perusahaan yang berkelanjutan selama suatu periode.

Menurut PSAK No.23 paragraf ke 23 (Revisi 2012) bahwa pendapatan adalah arus masuk bruto dari manfaat ekonomi yang timbul dari aktifitas normal entitas selama satu periode jika arus masuk itu mengakibatkan kenaikan ekuitas, yang tidak berasal dari kontribusi penanaman modal.

\section{Pengakuan Pendapatan}

Permasalahan utama dalam akuntansi untuk pendapatan adalah menentukan pengakuan pendapatan. Terkadang terdapat penyerahan barang atau jasa yang menghasilkan pendapatan pada saat yang sama dan ada kalanya penyerahan barang dan jasa dilakukan terlebih dahulu sedangkan imbalannya atau pendapatannya diterima kemudian. Maka disini timbul suatu masalah yang berkaitan dengan kapan suatu pendapatan itu diakui dan dicatat besarnya.

Menurut Simamora (2000, h.358) pengakuan adalah "proses formal mencatat dan melaporkan suatu pos dalam laporan keuangan".

Sedangkan menurut Skousen (2001, h.298) mengatakan bahhwa pendapatan selalu diakui pada saaat dua kreteria penting terpenuhi.

1. Pendapatan sudah diselesaikan (perusahaan sudah melakukan sesuatu).

2. Kas, atau keabsahan janji untuk pembayaran dimasa datang sudah diterima (perusahaan sudah menerima suatu sebagai pengembalian.

Pengakuan (recognition) berarti proses pembentukan suatu pos yang memenuhi definisi unsur kriteria pengakuan yang sesuai dengan standar akuntansi dalam laporan neraca dan laba rugi, yaitu Harahap (2011:96) menyatakan : 
1. Ada kemungkinan manfaat ekonomi yang berkaitan dengan pos tersebut akan mengalir dari atau ke dalam perusahaan.

2. Pos tersebut mempunyai nilai atau biaya yang dapat diukur dengan andal.

Belkaoui dalam Samsu (2013:569) menyatakan bahwa ada dua metode pengakuan pendapatan dalam periode akuntansi, yaitu:

1. Accrual Basis adalah Suatu basis akuntansi dimana transaksi ekonomi dan peristiwa diakui, dicatat, dan disajikan dalam laporan keuangan pada saat terjadinya transaksi tersebut tanpa memerhatikan waktu kas diterima atau dibayar. Beban dan pendapatan secara hati-hati disamakan. Menyediakan informasi yang lebih handal dan terpercaya tentang seberapa besar suatu perusahaan mengeluarkan uang atau menerima uang. Pencatatan menggunakan metode ini mengakui beban pada saat transaksi terjadi walaupun kas belum dibayarkan. Begitu pula dengan pendapatan. Pendapatan dicatat pada saat transaksi pendapatan terjadi walaupun kas atas transaksi pendapatan tersebut baru diterima bulan depan. Dalam hal ini maka dapat disimpulkan bahwa pencatatan menggunakan accrual basis lebih mencermikan keadaan perusahaan dan lebih dapat mengukur kinerja perusahaan.

2. Cash Basi, pendapatan diakui ketika kas diterima sedangkan beban diakui pada saat kas dibayarkan, artinya perusahaan mencatat beban didalam transaksi jurnal entry ketika kas dikeluarkan atau dibayarkan dan pendapatan dicatat ketika kas masuk atau diterima. Cash Basis merupakan salah satu konsep yang sangat penting dalam akuntansi, dimana Pencatatan basis kas adalah teknik pencatatan ketika transaksi terjadi dimana uang benar-benar diterima atau dikeluarkan. Dengan kata lain Akuntansi Cash Basis adalah basis akuntansi yang mengakui pengaruh transaksi dan peristiwa lainnya pada saat kas atau setara kas diterima atau dibayar yang digunakan untuk pengakuan pendapatan, belanja dan pembiayaan.

\section{Pengukuran Pendapatan}

Pengukuran pendapatan merupakan unsur-unsur yang sangat penting dalam laporan keuangan, karena dalam melakukan aktivitas usaha dan manajemen perusahaan tentu ingin mengetahui nilai atau jumlah pendapatan yang diperoleh dalam suatu periode akuntansi yang diakui sesuai dengan prinsip umum.

Riahi, et al (2006: 56) menyatakan bahwa "pengukuran memiliki arti pemberian angka-angka kepada atau objek atau kejadian-kejadian menurut aturan-aturan tertentu”.

Menurut Harahap (2011: 96) menyatakan bahwa pengukuran adalah proses penetapan jumlah uang untuk mengakui dan memasukkan setiap unsur laporan keuangan dalam neraca atau laporan laba rugi. 
Menurut Skousen dan Stice (Akbar, 2009 :568) ada lima dasar pengukuran yang biasanya digunakan dalam praktek yaitu :

1. Cost Historis (historical cost), yaitu harga tunai ekuivalen yang dipertukarkan untuk barang atau jasa pada tanggal perolehan atau akuisisi. Pada dasar pengukuran ini, aktiva dicatat sebesar pengeluaran kas (setara kas) atau sebesar nilai wajar imbalan yang diberikan untuk memperoleh aktiva tersebut pada data perolehan.

2. Cost Penggantian Terkini (current replacement cost), merupakan harga tunai yang akan dibayarkan sekarang untuk membeli atau mengganti jenis barang atau jasa yang sama yang tidak didiskontokan yang mungkin akan diperlukan untuk menyelesaikan kewajiban.

3. Nilai Pasar Terkini (current market value), merupakan harga tunai ekuivalen yang dapat diperoleh dengan menjual suatu aktiva dan likuidasi yang dilaksanakan secara terarah.

4. Nilai Bersih yang Dapat Direalisasi (net realisable value), merupakan jumlah kas yang diharapkan akan diterima atau dibayarkan dari hasil pertukaran aktiva atau kewajiban dalam kegiatan normal perusahaan. Pada umumnya, nilai bersih yang dapat direalisasi sama dengan harga jual dikurangi dengan biayabiaya penjualan normal.

5. Nilai Sekarang yang Didiskontokan (current discounted value), merupakan aktiva yang dinyatakan sebesar arus kas masuk bersih dimasa depan yang didiskontokan ke nilai dari pos yang diharapkan dapat memberikan hasil dalam pelaksanaan usaha normal kewajiban dinyatakan ke nilai sekarang yang diharapkan akan diperlukan untuk menyelesaikan kewajiban dalam pelaksanaan usaha.

\section{Pengakuan dan Pengukuran Pendapatan Berdasarkan PSAK No. 23}

Menurut PSAK No. 23 Paragraf 19 mengenai pengakuan pendapatan atas transaksi penjualan jasa adalah bila suatu transaksi yang meliputi penjualan jasa dapat diestimasi dengan andal bila seluruh kondisi berikut ini dipenuhi:

1. Jumlah pendapatan dapat diukur dengan andal.

2. Besar kemungkinan manfaat ekonomi sehubungan dengan transaksi tersebut akan diperoleh perusahaan.

3. Tingkat penyelesaian dari suatu transaksi pada tanggal neraca dapat diukur dengan andal.

4. Biaya yang terjadi untuk transaksi tersebut dan biaya untuk menyelesaikan transaksi tersebut dapat diukur dengan andal.

Menurut Ikatan Akuntansi Indonesia dalam pernyataan Standar akuntansi keuangan (PSAK) No.23 (2012:23.6) Menyatakan bahwa pengukuran pendapatan adalah "Pendapatan harus diukur dengan nilai wajar imbalan yang diterima atau dapat diterima."

Adapun penjelasannya lebih lanjut dari pernyataan tersebut yang dikemukakan Standar Akuntansi Keuangan (2012 :23.6) adalah jumlah pendapatan yang timbul dari suatu nilai transaksi biasanya ditentukan oleh persetujuan antara perusahaan dengan pembeli atau pemakai aktiva tersebut. Jumlah tersebut diukur dengan nilai wajar 
imbalan yang diterima atau yang dapat diterima perusahaan dikurangi jumlah diskon dagang dan rabat volume yang diperoleh perusahaan. Pada umumnya imbalan tersebut berbentuk kas atau setara kas dan jumlah pendapatan adalah jumlah kas atau setara kas ang diterima atau dapat diterima. Namun bil arus masuk dari kas atau setara kas di tangguhkan nilai wajar dari imbalan tersebut mungkin kurang dan jumlah nominal dari kas yang diterima atau yang dapat diterima.

Nilai wajar yang dimaksud dalam PSAK No.23 paragraf ke 23 (Revisi 2012) adalah jumlah suatu aset dipertukarkan atau liabilitas diselesaikan antara pihak-pihak yang berkeinginan dan memiliki pengetahuan memadai dalam suatu transaksi yang wajar.

Selanjutnya Standar Akuntansi Keuangan dalam PSAK (2012: 23.11) menerangkan bahwa bila barang atau jasa dipertukarkan (barter) untuk barang atau jasa dengan sifat dan nilai yang sama, maka pertukaran tersebut tidak dianggap sebagai transaksi yang mengakibatkan pendapatan.

\section{METODE PENELITIAN}

\section{Sejarah Perusahaan}

Perkumpulan Keluarga Berencana Indonesia (PKBI) suatu organisasi sosial, bergerak dibidang kependudukan dan Keluara Berencana didirikan pada tangal 23 Desember 1957, dan merupakan pelopor Gerakan Keluarga Berencana di Indonesia. Perkumpulan Keluarga Berencana Indonesia (PKBI) sebagai organisasi Lembaga Swadaya Masyarakat (LSM) ang peduli terhadap masalah Kesehatan Keluarga dan Kesehatan Reproduksi, didukung oleh para Relawan, yang tersebar di 27 Provinsi. Dalam rangka meningkatkan dan mewujudkan upaya kemandirian organisasi demi mendukung Program PKBI, PKBI membentuk Badan Usaha untuk mengelola usaha yang berjalan dan mengembangkan usaha baru. Pada tahun 2004 telah di dirikan PT. Bakti Grahasta Mandiri (BGM). Bisnis PT. BGM adalah di bidang jasa yang mulai beroperasi dijakarta. Jadi, Wisma PKBI dikelola oleh PT. Bakti Grahasta Mandiri yg bergerak dibidang jasa penginapan. Berjalanlah sebuah wisma yang bergerak dibidang jasa penginapan yang penuh kehangatan keluarga. Pada tahun 2008 ada pelebaran gedung dan penambahan kamar dan ruang rapat dan jumlah kamar menjadi 80, ruang meeting 7 dan cafeteria 1 ruangan. Para tamu umum yang menginap dan berkegiatan di PT. Bakti Grahasta Mandiri.

Sumber Pendapatan PT. Bakti Grahasta Mandiri diantaranya :

1. Pendapatan dari hasil Penjualan kamar

2. Pendapatan sewa ruang rapat

3. Pendapatan dari hasil penjualan makanan dan minuman

4. Pendapatan dari laundry 


\section{Tempat dan Waktu Penelitian}

Proses penelitian ini dilaksanakan dalam waktu 4 bulan (Oktober 2015 sampai dengan Januari 2016 ). Tempat penelitian yang dilakukan adalah pada PT. Bakti Grahasta Mandiri yang berlokasi di J1. Hang Jebat III/F3, Kelurahan Gunung, Kecamatan Kebayoran Baru, Jakarta Selatan.

\section{Desain Penelitian}

Desain penelitian merupakan rancangan penelitian yang digunakan sebagai pedoman dalam melakukan proses penelitian. Dalam penelitian ini, desain penelitian yang digunakan adalah penelitian deskriptif, dimana penelitian ini merupakan penelitian yang bertujuan untuk membuat deskripsi secara sistematis, factual dan akurat mengenai fakta-fakta dan sifat-sifat dari objek penelitian. Dan dapat memperoleh deskripsi data yang mampu menggambarkan komposisi dan karakteristik dari unit yang diteliti dalam penerapan PSAK No. 23 Pada PT. Bakti Grahasta Mandiri.

\section{Metode Pengumpulan Data}

Ada dua cara dalam pengumpulan data dalam penelitian ini yaitu :

a. Penelitian Kepustakaan (Libray Research)

Penelitian Kepustakaan ( Libray Research) adalah metode pengumpulan data dengan cara membaca dan mempelajari buku-buku yang ada dan sumber data yang lainnya penelitian yang berkaitan dengan pembahasan masalah yang dibutuhkan. berikut :

Teknik pengumpulan data pada penelitian ini dilakukan dengan cara sebagai

1. Teknik observasi yaitu mengumpulkan data secara detail dengan cara melakukan pengamatan langsung pada objek peneltian dengan cara mencatat temuan data-data.

2. Teknik survei dokumen dilakukan dengan cara melihat dokumendokumen yang berkaitan dengan PSAK No. 23.

b. Penelitian Lapangan (Field Research)

Penelitian lapangan yaitu suatu metode pengumpulan data dimana peneliti mengadakan pengamatan secara langsung ketempat objek yang diteliti dengan cara :

1. Teknik dokumentasi yaitu mengumpulkan data dan informasi melalui buku-buku, jurnal, internet dan dengan melakukan penelitian terhadap dokumen-dokumen dan laporan-laporan perusahaan yang berkaitan dengan penelitian.

2. Teknik wawancara yaitu melakukan tanya jawab secara langsung kepada pihak-pihak yang berkompeten untuk memberikan keterangan sehubungan dengan masalah yang diangkat penulis. 


\section{Jenis Data}

Jenis data yang digunakan dalam penelitian ini adalah data sekunder yang diperoleh atau dikumpulkan peneliti dari berbagai sumber yang telah ada. Data skunder dapat diperoleh dari berbagai sumber seperti buku, laporan dan jurnal dan lain-lain.

\section{Metode Analisis Data}

Data yang telah dikumpulkan adalah dengan menggunakan teknik analisis data deskriptif yang tediri dari :

a. Analisis Kualitatif merupakan suatu metode yang berusaha memberikan gambaran mengenai data atau kejadian berdasarkan fakta-fakta yang tampak pada situasi yang diselidiki peneliti dan objek yang diteliti terpisah, proses penelitian yang dilakukan melalui pengukuran dengan alat yang baku dan objektif.

\section{ANALISIS HASIL PEMBAHASAN}

\section{Hasil Analisis}

\section{Pengakuan Pendapatan Perusahaan}

Pengakuan pendapatan menurut prinsip berlaku umum pada PT. Bakti Grahasta Mandiri menjelaskan dalam hal kebijaksanaan mengenai pengakuan pendapatan sebagai hasil penjualan jasa kamar, ruang rapat, makanan dan minuman bagi tamu lebih mengacu pada pengakuan pendapatan berdasarkan konsep accrual basis, yakni pendapatan diakui pada saat terjadinya transaksi. Dimana pendapatan dan biaya secara hati-hati disamakan, dengan kata lain pendapatan harus sejalan dengan biaya pada periode tersebut. Dan untuk paket ruang rapat pengakuan pendapatanya berdasarkan metode accrual basis.

Untuk pendapatan laundry PT. Bakti Grahasta Mandiri mengakui pendapatannya berdasarkan metode accrual basis. PT. Bakti Grahasta Mandiri dari hasil pendapatan jasa kamar, ruang rapat, makanan dan minuman dapat dikatakan telah diperoleh atau dihimpun apabila telah dipakai atau telah dinikmati oleh tamu. Untuk paket rapat kegiatan dalam penjualan kamar, ruang rapat, makan dan minum untuk tamu perusahaan meminta uang deposit 50\% dari harga yang sudah ditentukan oleh perusahaan. Perusahaan akan mengeluarkan bill atau invoice tagihan untuk tamu yang menggunakan jasa kamar, ruang rapat, makan dan minum bagi tamu berupa kwitansi atau invoice.

\section{Pengukuran Pendapatan Perusahaan}

Pengukuran pendapatan pada PT. Bakti Grahasta Mandiri dilakukan berdasarkan harga atau tarif yang sudah ditentukan harus dibayar oleh tamu pada saat terjadinya 
transaksi. Harga atau tarif yang sudah ditentukan merupakan ukuran terbaik bagi pendapatan PT. Bakti Grahasta Mandiri pada saat terjadi penjualan jasa. Pendapatan diukur dengan nilai wajar imbalan yang diterima atau dapat diterima.

Nilai dari penjualan jasa tersebut menunukan nilai wajar yang diterima oleh PT. Bakti Grahasta Mandiri dalam bentuk kas. Dengan kata lain, jumlah yang diakui pada saat transaksi akan sama dengan jumlah yang akan diterima pada saat pelunasan. Begitu juga pada pendapatan jasa kamar, ruang rapat, makan dan minum, laundry itu semua dapat diukur sesuai dengan harga yang sudah ditentukan sebelumnya.

\section{Metode Pencatatan Perusahaan}

Pencatatan pendapatan setelah pengakuan dan pengukuran pada PT. Bakti Grahasta Mandiri ketika tamu masuk (check in) wajib membayar cash deposit satu malam sesuai harga atau tarif kamar yang dipilih, metode pencatatannya yaitu mendebit kas dan mengkredit pendapatan jasa kamar diterima dimuka. Selanjutnya realisasi pendapatan akan dicatat berdasarkan rekening tamu saat keluar (check out) sesuai dengan jasa yang diterima tamu tersebut. Selain jasa kamar seperti jasa ruang rapat, laundry, makanan dan minuman dan dicatat dengan mendebit kas diterima dan pendapatan jasa diterima dimuka serta mengkredit pendapatan jasa kamar dan lainnya.

\section{Hasil Pembahasan}

\section{Analisis Pengakuan Pendapatan Berdasarkan PSAK No. 23 Pada PT. Bakti Grahasta Mandiri}

Pada dasarnya ada 2 (dua) metode pengakuan pendapatan yaitu accrual basis dan cash basis. Dalam metode accrual basis ini pendapatan dan keuntungan diakui pada saat terjadi pendapatan. Misalnya dalam pendapatan jasa, jumlah pendapatan yang dicatat adalah pendapatan yang harga atau tarifnya sudah ditentukan oleh perusahaan dan akan langsung diakui sebagai pendapatan apabila jasa telah diberikan kepada tamu.

Pengakuan pendapatan PT. Bakti Grahasta Mandiri telah mengacu pada PSAK No. 23 karena nilai dari penjualan jasa yang dicatat sebagai pendapatan. Dari hasil analisis yang dilakukan pada PT. Bakti Grahsata Mandiri, perusahaan telah memenuhi standar sesuai dengan PSAK No. 23, dimana perusahaan telah mengakui pendapatan jasa pada saat jasa tersebut telah dilakukan atau dinikmati oleh tamu.

Maka pengakuan pendapatan pada PT. Bakti Grahasta Mandiri sesuai prinsip realisasinya dimana pendapatan diakui pada saat jasa telah diterima oleh tamu. Dapat dikatakan pengakuan pendapatan apapun yang digunakan oleh PT. Bakti Grahasta Mandiri, perusahaan konsisten dalam penggunaannya agar dapat menyelesaikan daya banding operasional perusahaan dari periode ke periode berikutnya. 


\section{Analisis Pengukuran Pendapatan Berdasarkan PSAK No. 23 Pada PT. Bakti Grahasta Mandiri}

Pengukuran pendapatan pada PT. Bakti Grahasta Mandiri ditentukan berdasarkan harga atau tarif penjualan jasa, serta menunjukan besarnya kas ekuivalen yang akan diterima perusahaan. Dengan demikian, pengukuran pendapatan telah sesuai dengan PSAK No. 23 Standar Akuntansi Keuangan yang menyatakan bahwa pengukuran pendapatan diukur dengan nilai wajar imbalan yang diterima atau yang akan diterima oleh PT. Bakti Grahasta Mandiri. Dalam pengukuran pendapatan yang diterapkan oleh PT. Bakti Grahasta Mandiri, menggunakan dasar historis dimana pendapatan diukur berdasarkan nilai wajar yang harga atau tarifnya sudah ditentukan oleh perusahaan tersebut. Pendapatan historis diukur dengan nilai wajar imbalan yang diterima atau dapat diterima. Nilai wajar imbalan yang diterima atau dapat diterima ini diukur dengan nilai harga atau tarif yang sudah ditentukan.

\section{KESIMPULAN DAN SARAN}

\section{Kesimpulan}

Pengakuan pendapatan yang diterapkan oleh perusahaan PT. Bakti Grahasta Mandiri adalah accrual basis dimana konsep ini keuntungan diakui pada saat terjadi transaksi. PT. Bakti Grahasta Mandiri memiliki beberapa sumber pendapatan, yaitu: pendapatan ruangan, pendapatan kamar, pendapatan makanan , minuman dan laundry. Perusahaan secara teoritis telah memahami baik tentang konsep pendapatan pada saat pengakuan dan pengukuran pendapatan, dan dalam prakteknya juga telah diterapkan sesuai PSAK Nomor 23.

\section{Pengakuan PT. Bakti Grahasta Mandiri}

Pengakuan pendapatan pada PT. Bakti Grahasta Mandiri menjelaskan dalam hal kebijaksanaan mengenai pengakuan pendapatan sebagai hasil dari penjualan kamar, ruang rapat, laundry, makanan dan minuman lebih mengacu pada konsep accrual basis. Pengakuan pendapatan atas jasa tamu PT. Bakti Grahasta Mandiri, perusahaan telah memenuhi standar dengan PSAK No. 23, dimana perusahaan telah mengakui pendapatan jassa pada saat jasa tersebut telah dilakukan atau dinikmati oleh tamu. Maka pengakuan pendapatan pada PT. Bakti Grahsta Mandiri tersebut sesuai dengan prinsip realisasinya dimana pendapatan diakui pada saat jasa telah diterima oleh tamu. Dan pembayaran oleh jasa tamu dilakukan secara cash atau tunai. Pada PT. Bakti Grahasta Mandiri sebagai hasil dari pendapatan jasa kamar, ruang rapat, makan dan minum dan laundry, dapat dikatakan apabila pemakai jasa tersebut telah membayar secara tunai. Saat itu PT. Bakti Grahasta Mandiri akan mengeluarkan guest bill atau invoice kepada tamu untuk melakukan pembayaran. 


\section{Pengukuran PT. Bakti Grahasta Mandiri}

Perusahaan secara teoritis telah memahami baik tentang konsep pendapatan pada saat pengakuan dan pengukuran pendapatan, dan dalam prakteknya telah diterapakan sesuai PSAK No. 23. Pengukuran pendapatan pada PT. Bakti Grahasta Mandiri dilakukan berdasarkan harga atau tarif yang sudah ditentukan. Pendapatan jasa kamar, ruang rapat, makan dan minum, laundry itu semua dapat diukur sesuai dengan harga yang sudah ditentukan oleh PT. Bakti Grahasta Mandiri. Pengukuran pendapatan dilakukan berdasarkan jumlah uang yang diterima atau pendapatan diukur dengan nilai wajar imbalan yang diterima atau yang akan diterima perusahaan.

\section{Saran}

Dari hasil analisis penulis memberi saran-saran atas berbagai hal yang di anggap perlu dalam batas kemampuan penulis, yaitu :

1. Perlakuan akuntansi pendapatan khususnya pengakuan dan pengukuran pendapatan PT. Bakti Grahasta Mandiri hendaknya dipertahankan dan diterapkan secara konsisten disetiap periode akuntansi agar menghasilkan laporan keuangan yang lebih akurat dala mencerminkan posisi keuangan dan hasil operasi perusahaan

2. Sedangkan metode accrual basis yang telah diterapkan oleh PT. Bakti Grahasta Mandiri telah sesuai dengan Standar Akuntansi Keuangan, maka diharapkan perusahaan untuk tetap menjalankan hal tersebut dalam mengelolah keuanganya.

3. Bagi peneliti selanjutnya, sebaiknya menambah variabel lainnya diluar variabel diluar yang telah diteliti, dan dapat bermanfaat secara teoritis dalam menambah wawasan untuk pengembangan penelitian lebih lanjut tentang pengakuan dan pengukuran pendapatan menurut PSAK No. 23.

\section{DAFTAR PUSTAKA}

Budi Mulia. 2007, Pengakuan dan Pengukuran Pendapatan Menurut PSAK No. 23 Pada PT. Raya Utama Travel Medan Skripsi, Fakultas Ekonomi Sumut.

Belkoui, Ahmed Riahi 2006, Accounting Theory, Teori Akuntansi, Edisi Kelima, Salemba Empat, Jakarta.

Deddi Nordiawan. 2009, Akuntansi Pemerintahan, Salemba Empat Jakarta.

Harahap, Sofyan Syafri. 2011. Teori Akuntansi. Edisi Revisi 2011. RadaGrafindo Persada. Jakarta.

Ikatan Akuntan Indonesia. 2010. Standar Akuntansi Keuanagn. Salemba Empat. Jakarta.

Kieso, Donald E, Weygadt dan Warfield. 2007, Akuntansi Intermediate, edisi ke dua belas, jilid 2, Erlangga Jakarta.

Simamora, Henry 2000, Akuntansi Basis Pengambilan Keputusan Bisnis, Jilid Satu, Cetakan Pertama, Salemba Empat, Jakarta. 
Soemarso. 2003, Akuntansi Suatu Pengantar, Edisi Kelima, Salemba Empat, Jakarta. Santoso, Imam. 2010. Akuntansi Keuangan Menengah (Intermediate Accounting). Baku Satu. Refika Aditama Bandung.

Worung, Yefie Ignasia. 2012. Analisis Penerapan PSAK No. 23 Terhadap Pengakuan dan Pengukuran Pendapatan pada PT. Telekomunikasi Indonesia Kandatel Manado. Skripsi. Universitas Sam Ratulangi. 